RFP-2358

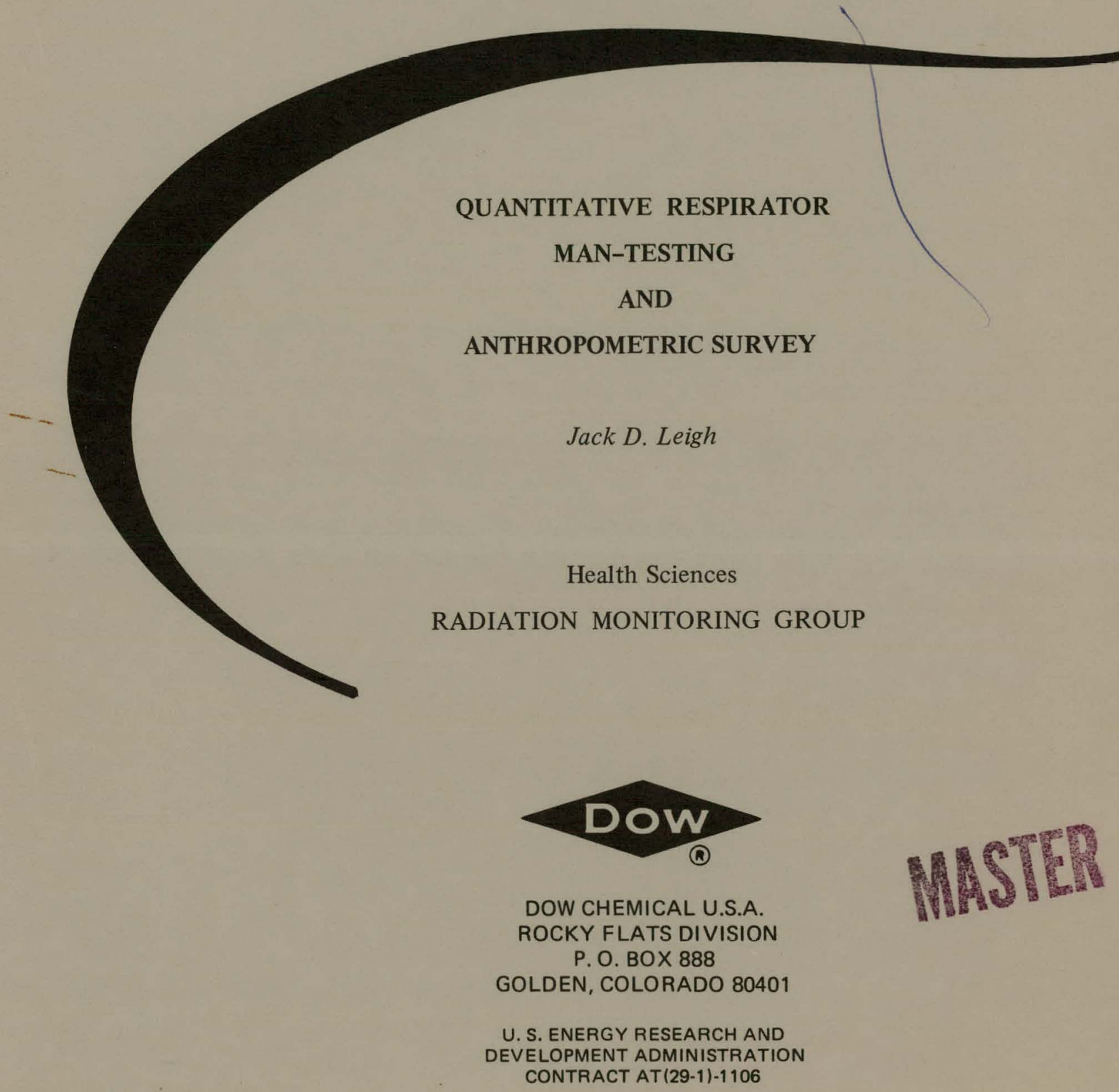




\section{DISCLAIMER}

This report was prepared as an account of work sponsored by an agency of the United States Government. Neither the United States Government nor any agency Thereof, nor any of their employees, makes any warranty, express or implied, or assumes any legal liability or responsibility for the accuracy, completeness, or usefulness of any information, apparatus, product, or process disclosed, or represents that its use would not infringe privately owned rights. Reference herein to any specific commercial product, process, or service by trade name, trademark, manufacturer, or otherwise does not necessarily constitute or imply its endorsement, recommendation, or favoring by the United States Government or any agency thereof. The views and opinions of authors expressed herein do not necessarily state or reflect those of the United States Government or any agency thereof. 


\section{DISCLAIMER}

Portions of this document may be illegible in electronic image products. Images are produced from the best available original document. 


\section{-LEGAL NOTICE}

This report was prepared as an account of work sponsored by the United States Government. Neither the United States nor the Energy Research and Development Administration, nor any of their employees, nor any of their contractors, subcontractors, or their employees, makes any warranty, expressed or implied, or assumes any legal liability or responsibility for the accuracy, completeness or usefulness of any information, apparatus, product or process disclosed, or represents that its use would not infringe privately owned rights.

Printed in the United States of America

Available from the

National Technical Information Service

U. S. Department of Commerce

Springfield, Virginia 22151

Price: Printed Copy $\$ 4.00$ Microfiche $\$ 2.25$ 
Printed

May 22, 1975
RFP-2358

UC-41 HEALTH AND SAFETY

TID-4500-R62

\section{QUANTITATIVE RESPIRATOR \\ MAN-TESTING \\ AND

\begin{abstract}
ANTHROPOMETRIC SURVEY
\end{abstract}
Jack D. Leigh

Health Sciences

RADIATION MONITORING GROUP

\section{SUBJECT DESCRIPTORS}

Anthropometry Respirators

\author{
DOW CHEMICAL U.S.A. \\ ROCKY FLATS DIVISION \\ P. O. BOX 888 \\ GOLDEN, COLORADO 80401 \\ Prepared under Contract AT(29-1)-1106 \\ for the \\ Albuquerque Operations Office \\ U.S. Energy Research and Development Administration
}

- NOTICE

This report was prepared as an account of work sponsored by the United States Government. Neither the United States nor the. United States Energy Research and Development Administration, nor any of their emplnyees, nor any of lleir contractors, subenntractors, or tliei employès, makes any warranty, express or implied, or assumes any-legal liability or responsibility for the accuracy, completeness or usefulness of any information, apparatus, product or process disclosed, or repressents that its use would not infinginge privately owned rights. 
RFP-2358

THIS PAGE INTENTIONALLY LEFT BLANK 


\section{CONTENTS}

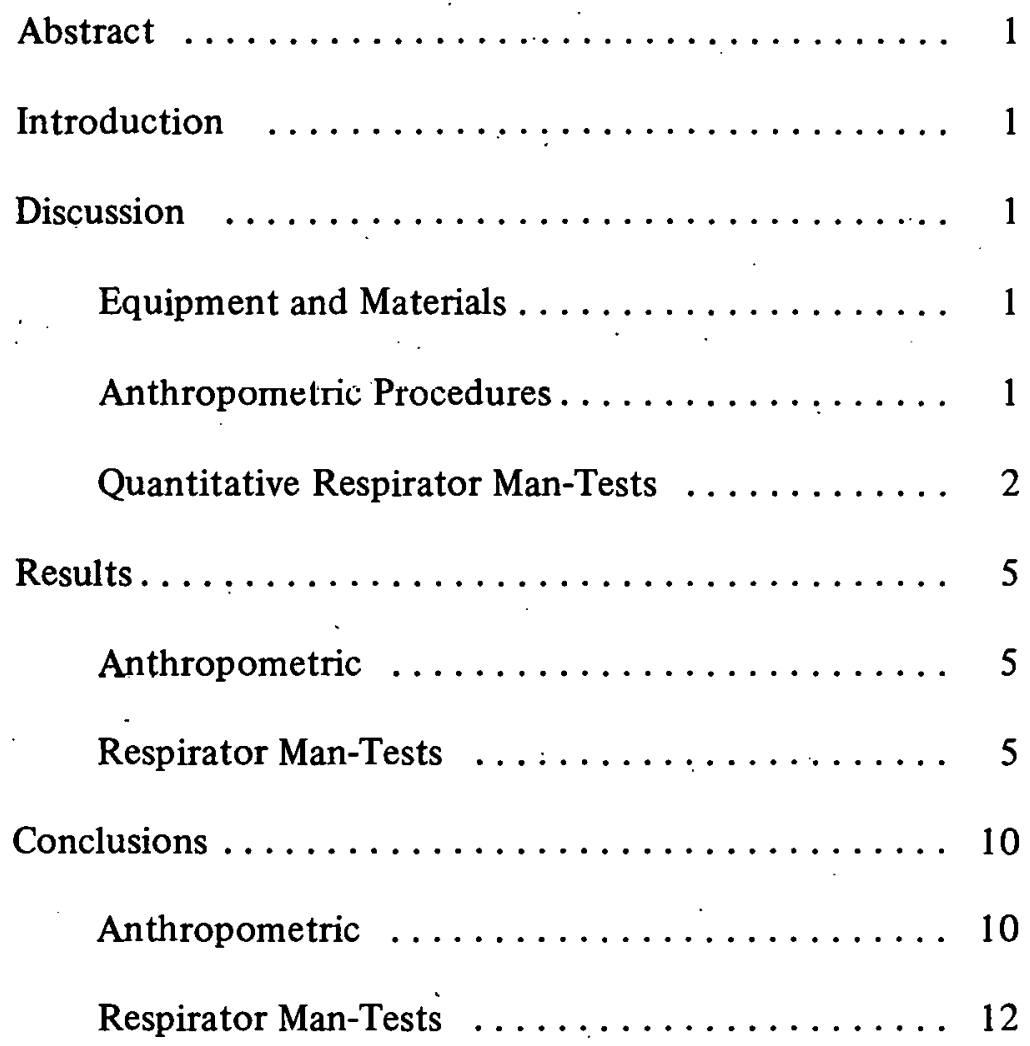


RFP-2358

\section{A CKNOW L E D G M E T S}

Appreciation and thanks are expressed to Patty Jo Baker, Pattie Hines, and Cynthia Morrison for their diligent efforts to obtain and compile the report data. 


\title{
QUANTITATIVE RESPIRATOR MAN-TESTING AND \\ ANTHROPOMETRIC SURVEY
}

\author{
Jack D. Leigh
}

\begin{abstract}
Results are reported of a recent anthropometric survey and test procedures related to the respiratory protection program to safeguard the health of personnel. Respiratory protection procedures involve the selection of face masks worn by plant personnel. The fitting, handling, and use of face masks through explicit instructions can assure optimum safeguards.
\end{abstract}

Comparisons are made with the test-panel selection parameters established by the Los Alamos Scientific Laboratory in Los Alamos, New Mexico, and recommendations by Webb Associates of Yellow Springs, Ohio.

\section{INTRODUCTION}

The primary objective of a respiratory protection program is the health and safety of personnel involved in plant operations. Management stresses emphasis and cooperation to provide optimum safeguards. In February 1973, a quantitative respirator test program for employees was initiated.

To complement the program in 1974 , an anthropometric (facial) survey of plant personnel was conducted. The report data have been compared to the test-panel selection parameters established by the Los Alamos Scientific Laboratory (LASL), Los Alamos, New Mexico, ${ }^{1}$ and Webb Associates of Yellow Springs, Ohio.

\section{DISCUSSION}

\section{Equipment and Materials:}

Space allotted for man-testing is a 20 by 25 -foot ( 6 by 8 -metre) room. The test chamber, equipped

\footnotetext{
${ }^{1}$ Alan Hack et al. Selection of Respirator Test Panels Representutive of U. S. Adult Facial Sizes. LA-5488. Los Alamos Scientific Laboratory, Los Alamos, New Mexico. March 1974.
}

with a 5 by 7 -foot ( 1.5 by 2 -metre) airlock, measures 13 by 7 feet (4. by 2 metres).

Table $I$ lists the equipment and respirators in use at Rocky Flats Plant.

\section{Anthropometric Procedures:}

With the prime emphasis on personnel safety, the program also focuses on the development of the technician administering the tests. Maintaining a businesslike and efficient approach, the technician at the same time must generate an air of confidence and interest in the benefits of testing for employee safety. The words, actions, and instructions to the employee should express assurance to encourage full cooperation, as well as a relaxed atmosphere during tests. The steps initiated to achieve these objectives follow:

1. A brief explanation of the purpose of the study was given to each employee whose facial configurations were to be measured for mask fits.

2. To determine the placement of the caliper for measuring the width of an employee's face, slight-finger pressure was applied to the zygomatic bone region, approximately 2 to 4 centimetres $(\mathrm{cm})$ anterior to the ear. Both sides of the face were marked at the widest point and the caliper tips were placed on these marked areas. Pressure was applied such that the caliper tips made a slight indentation in the facial tissue (Figure 1).

3. The length of the face was determined by placing one caliper tip at the nasal-root depression and the other tip under the chin. The caliper is tightened so that the tips cause only a slight indentation in the facial tissue (Figure 2). 
TABLE I. Equipment and Materials for Respiratory Protection Program.

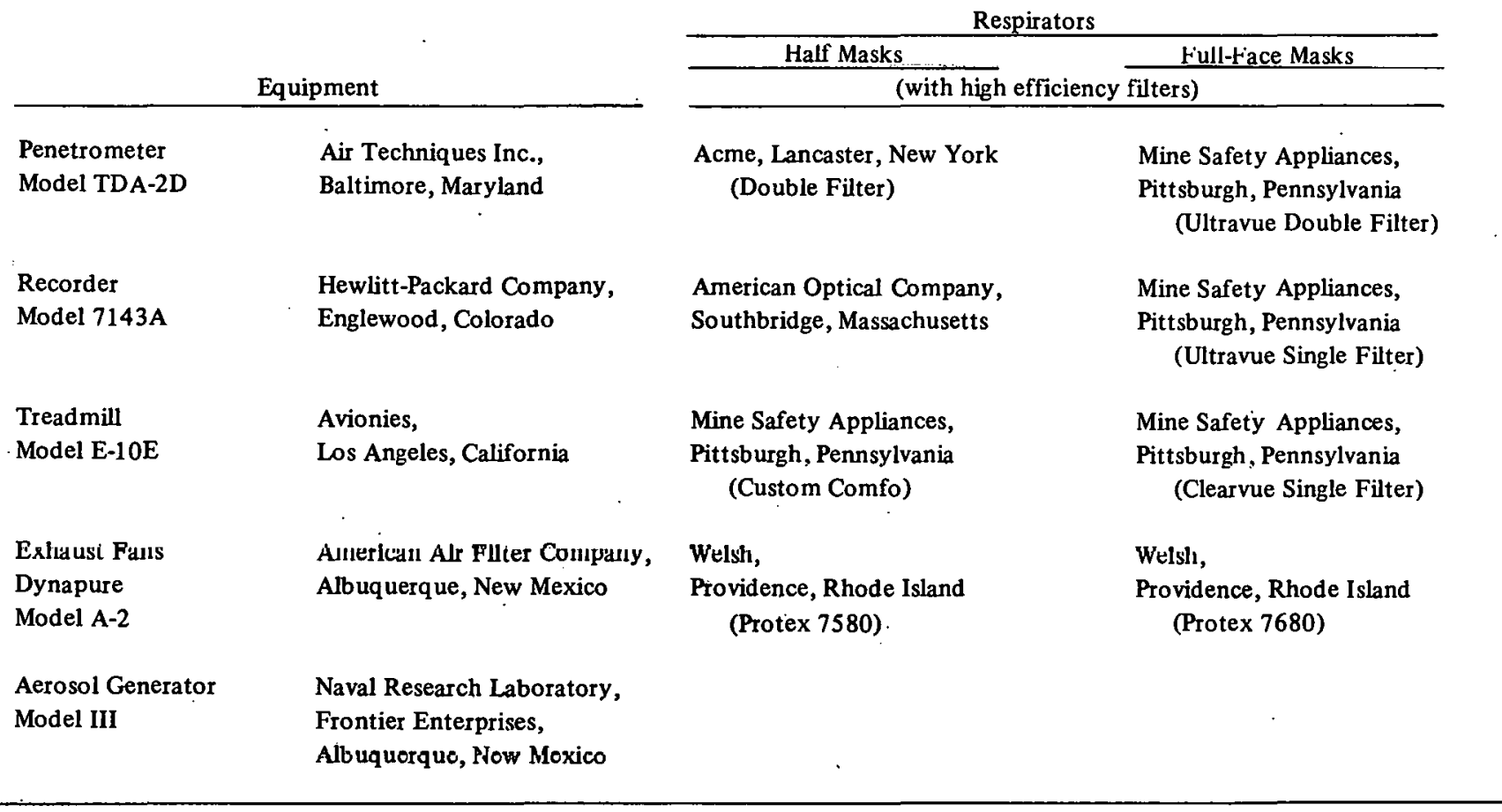

4. Two measurements were taken of the lips, one with the mouth relaxed and the other with the employee smiling. The distance between the corners of the mouth were measured in both situations.

5. All measurements were recorded in millimetres (mm).

\section{Quantitative Respirator Man-Tests:}

Prior to tests with personnel, the technician gives a $35-\mathrm{mm}$ slide and sound presentation to orient the subjects and explain the program. A quantitative respirator man-testing technique consisting of polydispersed di 2-ethylhexyl phthalate (DOP) with a light-scattering geometric mean-diameter particle size of 0.7 micrometres is employed at Rocky Flats. Equipment needed for the tests follows:

1. A supply of every type of respirator used at Rocky Flats, each equipped with high efficiency filters and a sampling port.
2. A forward light-scattering photometer with a strip-chart recorder for measuring and recording any aerosol that leaks into the test respiralur.

3. Sampling tubes from the test respirator to the pholometer and from the inteiviu of the lest chamber to the photometer. The two tubes must have identical inside diameters.

4. An aerosol generator activated by a flow of compressed air and equinped with a regulating valve for the incoming air, and an impactor.

5. A vacuum source for drawing air from the test chamber or the test respirator through the photometer.

6. A flow meter and control valve for controlling the rate of air flow through the photometer.

7. A system of scheduling employees for testing and of filing test results. 


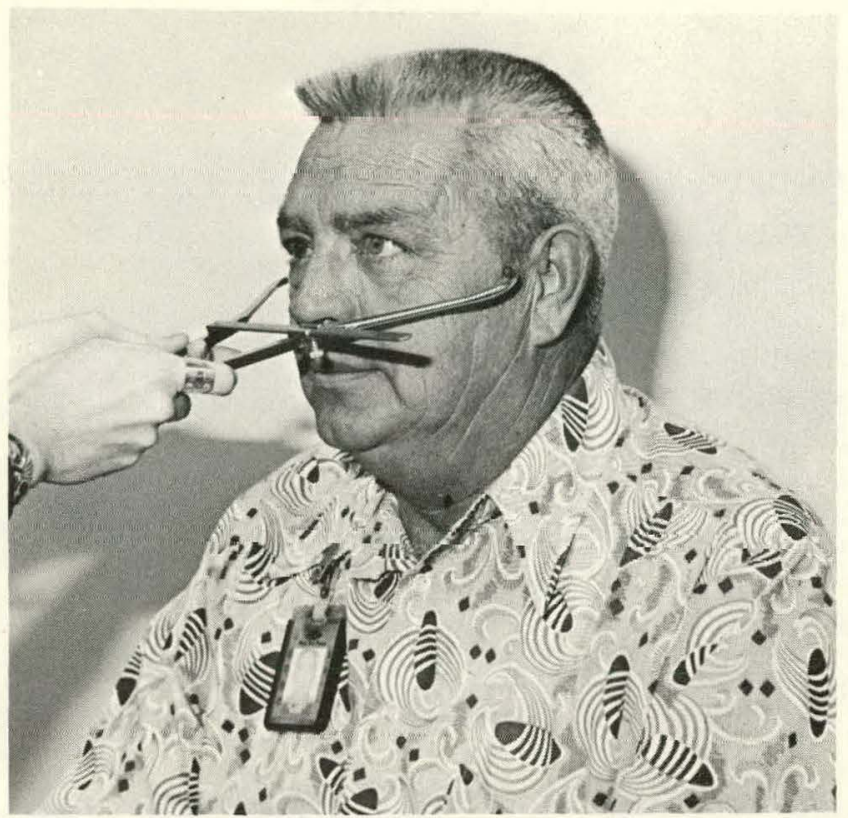

19217-3

FIGURE 1. Measuring Width of Employee's Face.

The following procedures are observed by the respiratory protection technician.

1. Asks each employee, before testing, to complete a Rocky Flats information card. This card is designed to make each employee more aware of any possible physical or mental limitations he may have. If any such limitations are indicated or known, the Medical Department personnel would be consulted. Their advice determines whether to continue, limit, or delete parts or all of the test (Figure 3).

2. Makes a visual inspection of the face of each person to detect whether hair or scars could interfere with the proper seal of a face mask.

3. Explains how communications with an employee in the test chamber are accomplished.

4. Explains the nine exercises each employee is asked to perform:

a. Normal breathing.

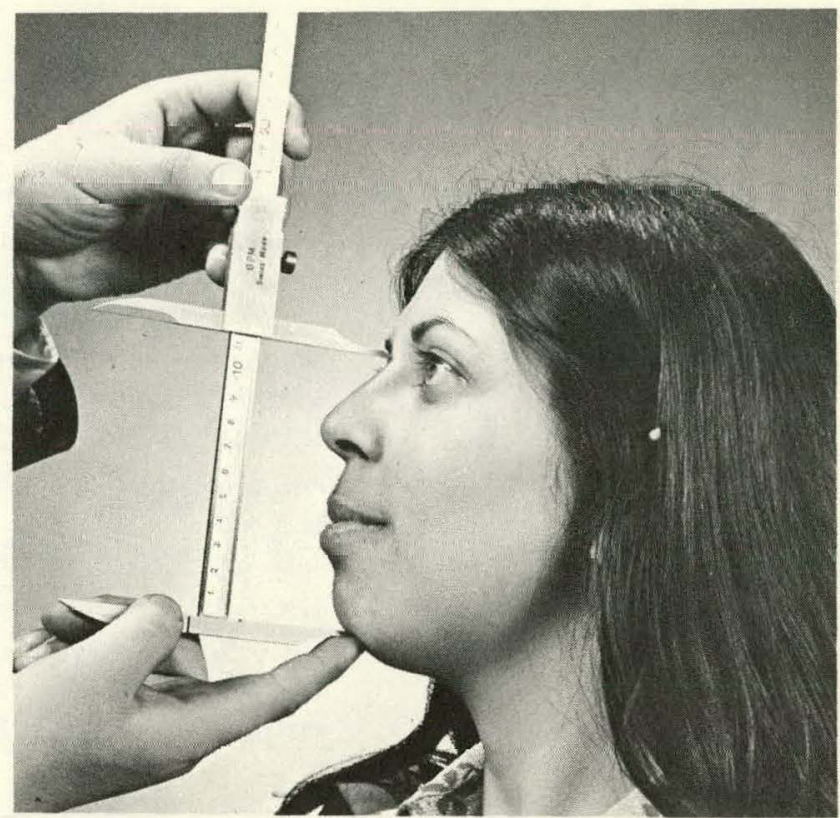

$19268-8$

FIGURE 2. Measuring Length of Employee's Face.

b. Deep breathing.

c. Smile.

d. Frown.

e. Cough.

f. Hands on hips, bend forward at the waist, move the head from side to side.

g. Hands above the head, move the head up and down.

h. Talk.

i. Walk on treadmill.

5. Ensures that each employee is tested with all available respirators.

6. After testing is completed, determines which half mask and full-face mask will provide the 


\section{QUANTITATIVE RESPIRATOR MAN-TEST INFORMATION CARD}

1. Do you have any concern about your ability to obtain an adequate air supply while using respiratory protection equipment during a job?

\section{YES}

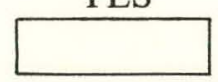

NO

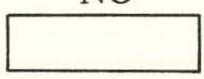

2. Do you have any known respiratory ailments that could affect your ability to wear respiratory protection devices properly?

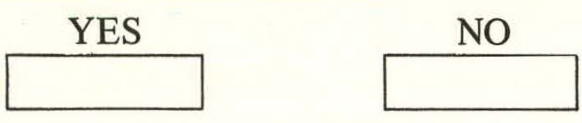

3. Do you have any known heart condition that could affect your ability to wear respiratory protection devices?

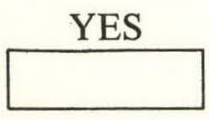

NO

If your answer is YES, please indicate the date of the last illness.

4. If at any time there are any changes in your facial features, such as new dentures, scars, gain or lose of weight or any other thing that may create a change in the type of respirator you should wear or the way a respirator fits, you should notify your supervisor and arrange for a re-test.

NAME

DATE

RFT-263 (9-74)

FIGURE 3. Rocky Flats Information Card. 
subject employee with the highest degree of protection.

7. Records the information from Item 6 on Form RF-46213 MHS-3, Respirator Fitting Card. This form is given to the employee for his record (Figure 4).

8. Completes the Respiratory Protection Program work sheet [Form No. RF-46214 (9-74) MHS-3]. The completed form is used to transfer information to a computer. The computer output is considered the permanent record for each employee tested (Figure 5).

\section{RESULTS}

\section{Anthropometric:}

Results of the anthropometric facial survey of 1,467 employees (1,340 males and 127 females) are best

FIGURE 4. Front and Back of Information Fitting Card.

\section{ROCKY FLATS PLANT}
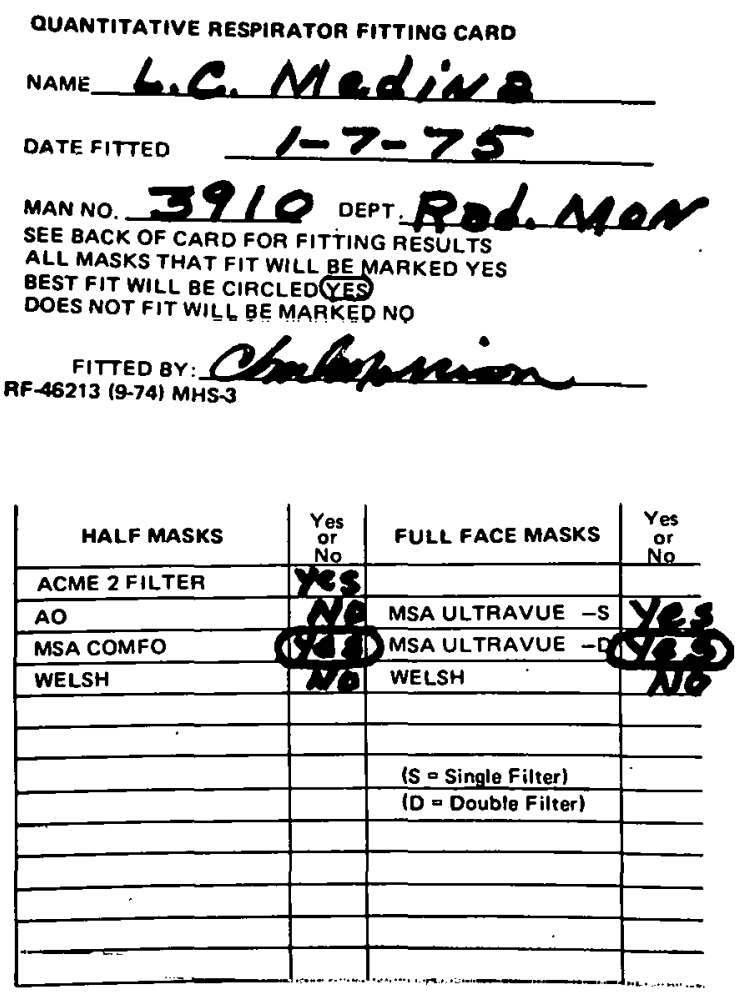

defined by the following diagrams (see Figures 6 and 7). The outlined area is the test-panel selection area established by LASL and Webb Associates for half-mask respirators. Out of the 1,467 Rocky Flats employees tested, $10.3 \%$ had measurements falling outside of the selection area.

The outlined area in Figure 7 is the test-panel selection area established by LASL and Webb Associates for full-face respirators. Of the 1,467 employees measured, $12.6 \%$ were outside of this area.

\section{Respirator Man-Tests:}

Results of the quantitative respirator man-tests of Rocky Flats employees can best be reported as in Table II. Abbreviations for the different half.masks and full-face masks are identified as follows:

FIGURE 5. Respiratory Protection Program Work Sheet.

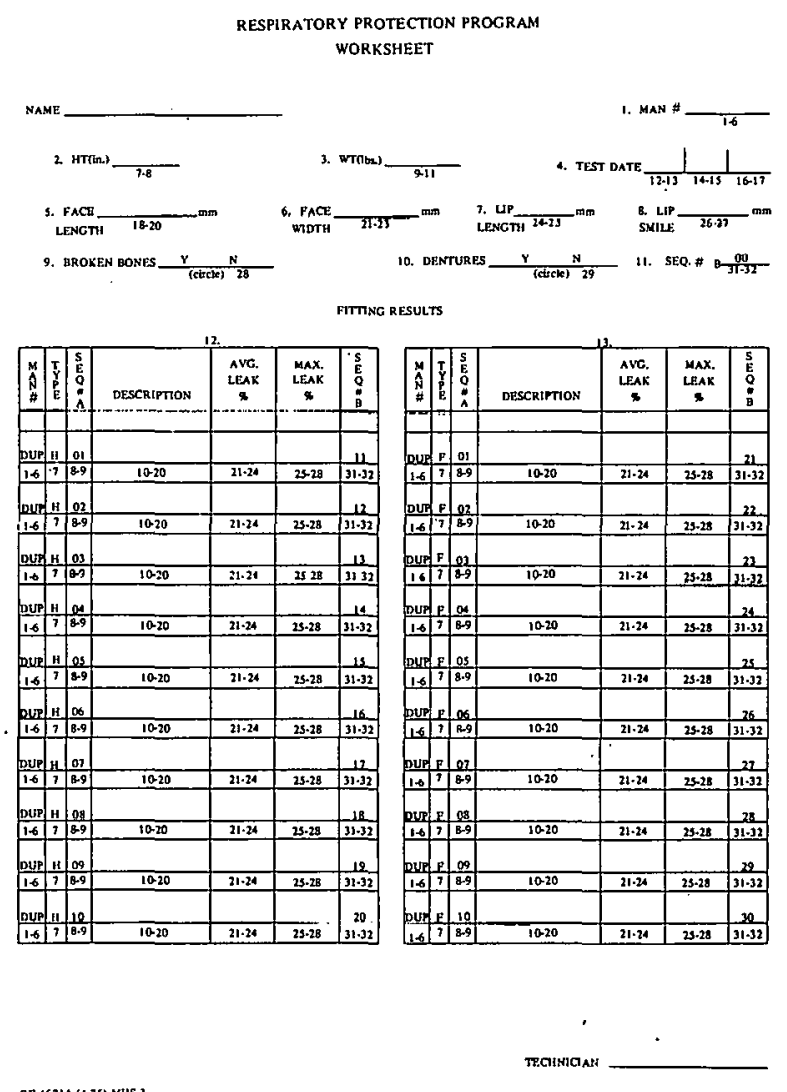




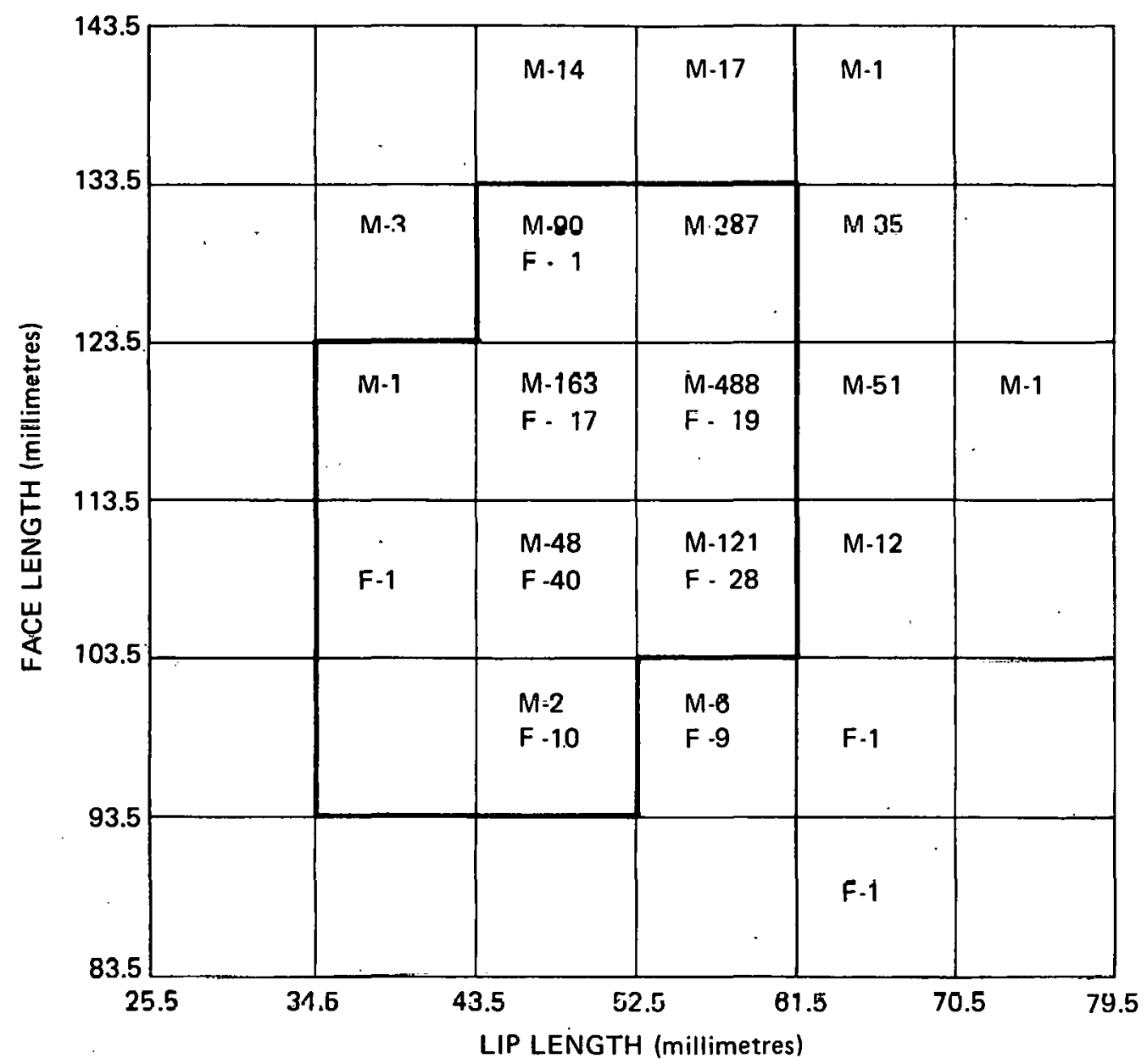

FIGURE 6. Results of Survey with Half-Mask Respirators. (Number of persons tested: $\mathrm{F}$ for females and $\mathrm{M}$ for males.) 
RFP-2358

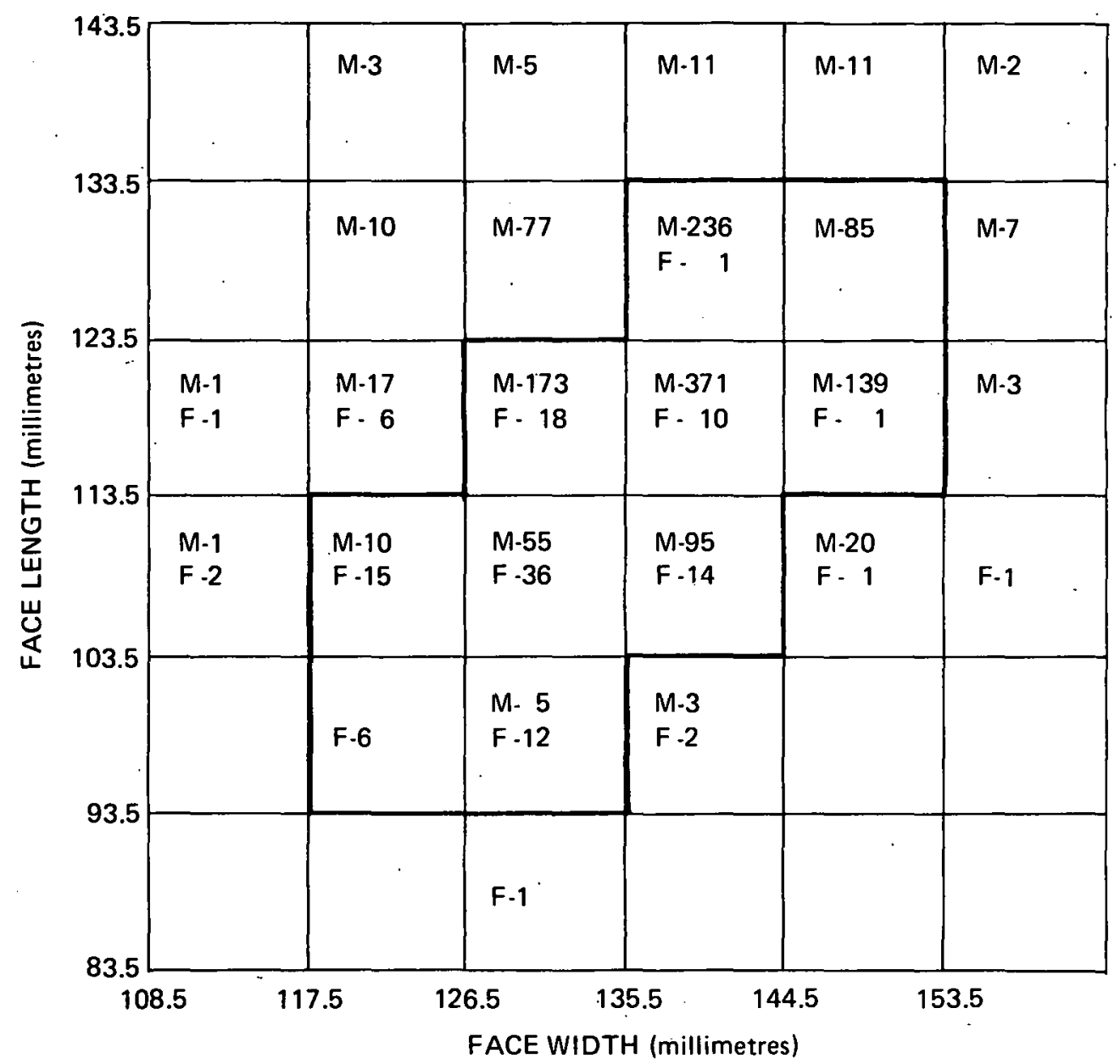

FIGURE 7. Results of Survey with Full-Face Respirators.

(Number of persons tested: $\mathrm{F}$ for females and $\mathrm{M}$ for males.) 


\begin{tabular}{|c|c|c|}
\hline Half Masks: & $\mathrm{ACM}$ & - Acme \\
\hline & AO & - American Optical \\
\hline & $\mathrm{COM}$ & - Custom Comfo \\
\hline & WEL & - Welsh \\
\hline Full-Face Masks: & CL-S & $\begin{array}{l}\text { - Clearvue Single } \\
\text { Filter }\end{array}$ \\
\hline & UV-D & $\begin{array}{l}\text { - Ultravue Double } \\
\text { Filter }\end{array}$ \\
\hline & UV-S & $\begin{array}{l}\text { - Ultravue Single } \\
\text { Filter }\end{array}$ \\
\hline & WEL & $\begin{array}{l}\text { - Welsh Pratex } \\
\text { Double Filter }\end{array}$ \\
\hline
\end{tabular}

Of the 1,467 employees measured, 691 (666 males and 25 females) were also fitted with the half-mask respirator. Figure 8 shows the best-fit mask as determined by quantitative respirator man-tests. The outlined area is the test-panel selection area established by LASL and Webb Associates for halfmask respirators.

Of the 1,467 employees measured, 662 (652 males and 10 females) were fitted with a full-face respirator. Figure 9 shows the best-fit mask as determined by quantitative respirator man-tests. The outlined area is the test-panel selection area

TABLE II. Results of Respirator Man-Tests.

Composite of lowest leakage (best fit) obtained by each employee with appropriate respirator indicated. The figures in each column represent number of employecs. Each employee appears once in the half-mask sectinn and once in the full-face mask section.

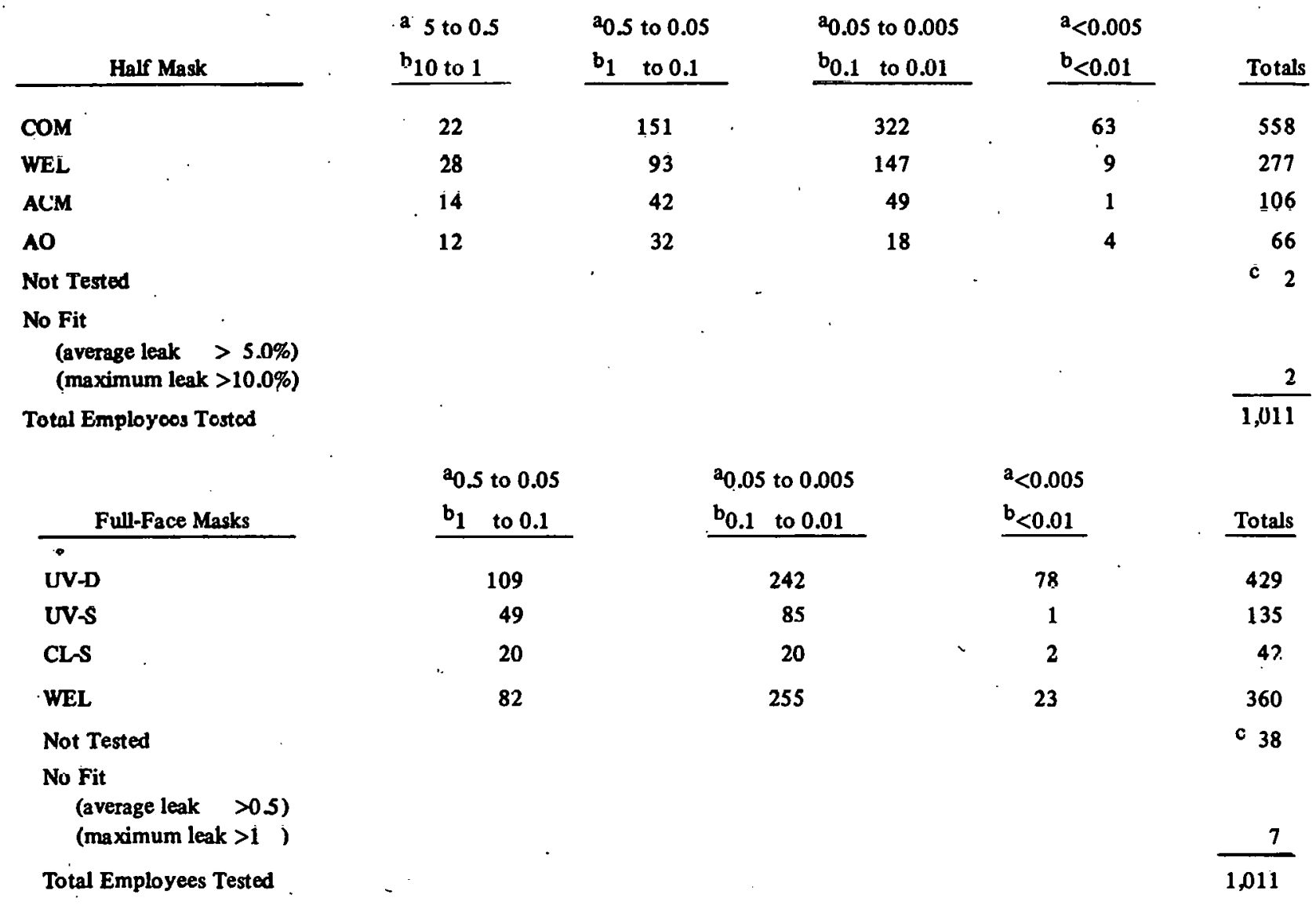

average leak in percent.

baximum leak in percent.

$\mathrm{c}_{\text {Fifteen were not tested because of medical limitations. Twenty-five were }}$ not tested because of nonrelated function as for those of office employees. 
RFP-2358

FIGURE 8. Results with Half-Mask Respirators.

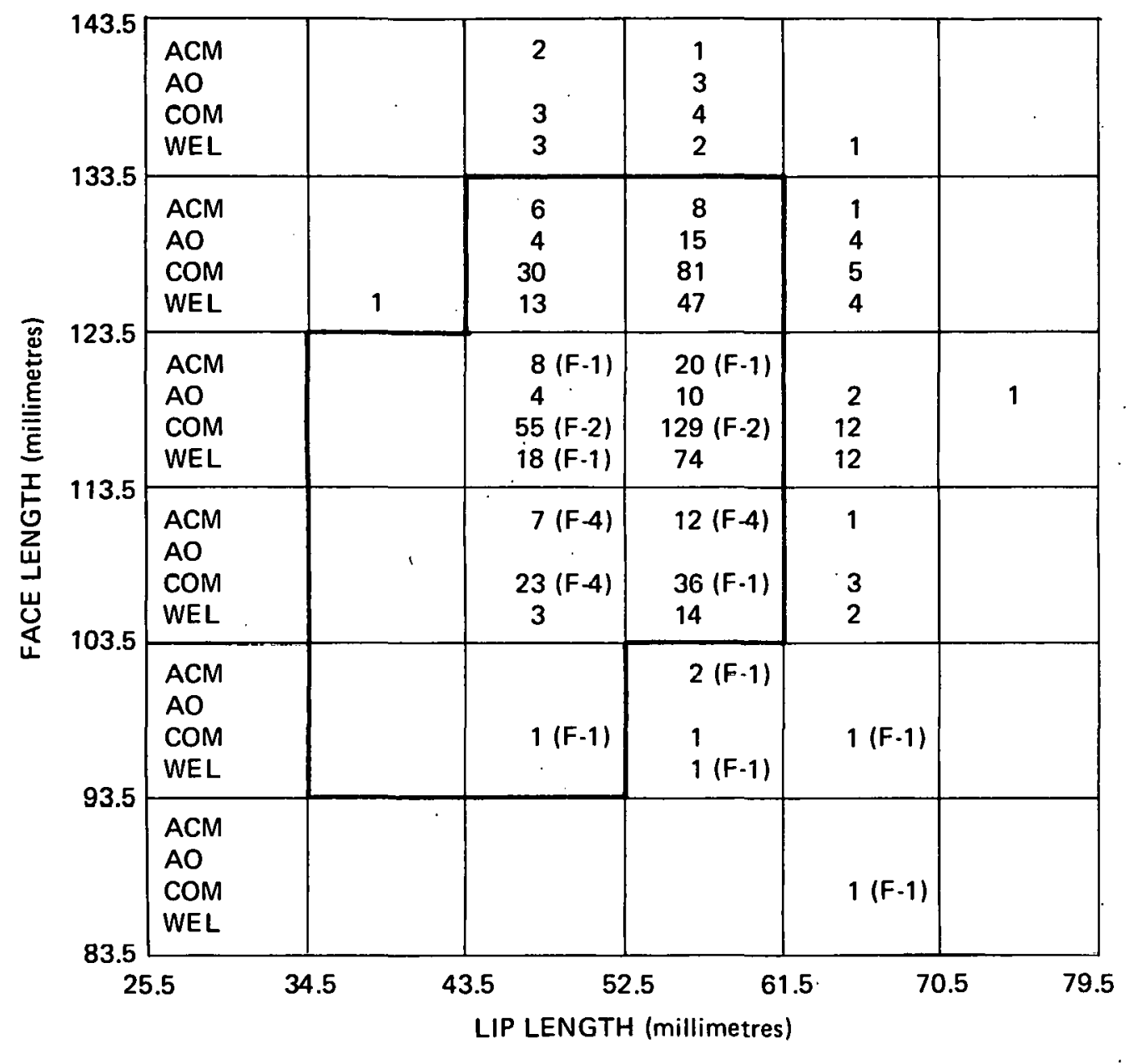


RFP-2358

established by LASL and Webb Associates for full-face respirators.

\section{CONCLUSIONS}

Anthropometric:

The 1,467 employees measured during the anthropometric facial survey represent a limited but fair cross section of the industrial population. During the survey, no physical factors such as height, weight, age, and sex were considered. Upon comparing the distribution of the Rocky Flats employees measured to the test-panel selection areas established by LASL and Webb Associates for the half-mask respirator (Figure 6), a shitt to the right (as indicated by the broken line diagram in Figure 10) suggests that a more representative test-panel selection area could be determined. In Figure $6,10.3 \%$ of the employees were outside of the selection arca. In Figure 10 only $2.7 \%$ of the employees are outside of the suggested test-panel selection area.

Apply the same basic parameters, as with the halfmask respirators, to the LASL and Webb Associates Test-Panel selection area for full-face respiratore (see Figure 7). The conclusion that a change would be advantageous becomes apparent. The broken line diagram in Figure 11 depicts this proposed change for full-face respirators. This change would reduce the number of Rocky Flats employees outside of the selection area from $12.6 \%$ to $4.8 \%$.

The anthropometric facial survey of Rocky Flats employees will be continued.

FIGURE 9. Results with Full-Mask Respirators.

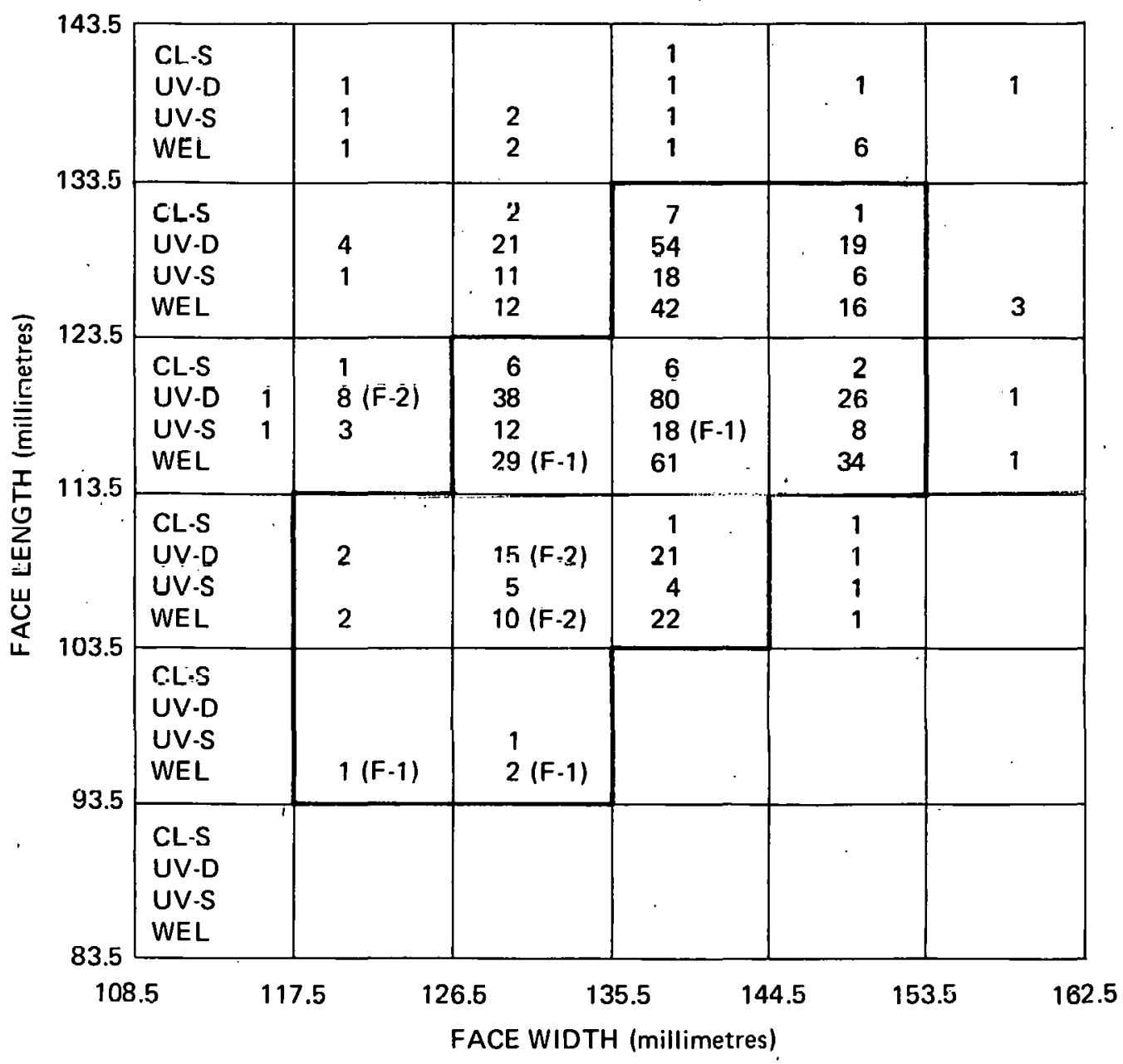


FIGURE 10. Comparative Dața for Half Masks.

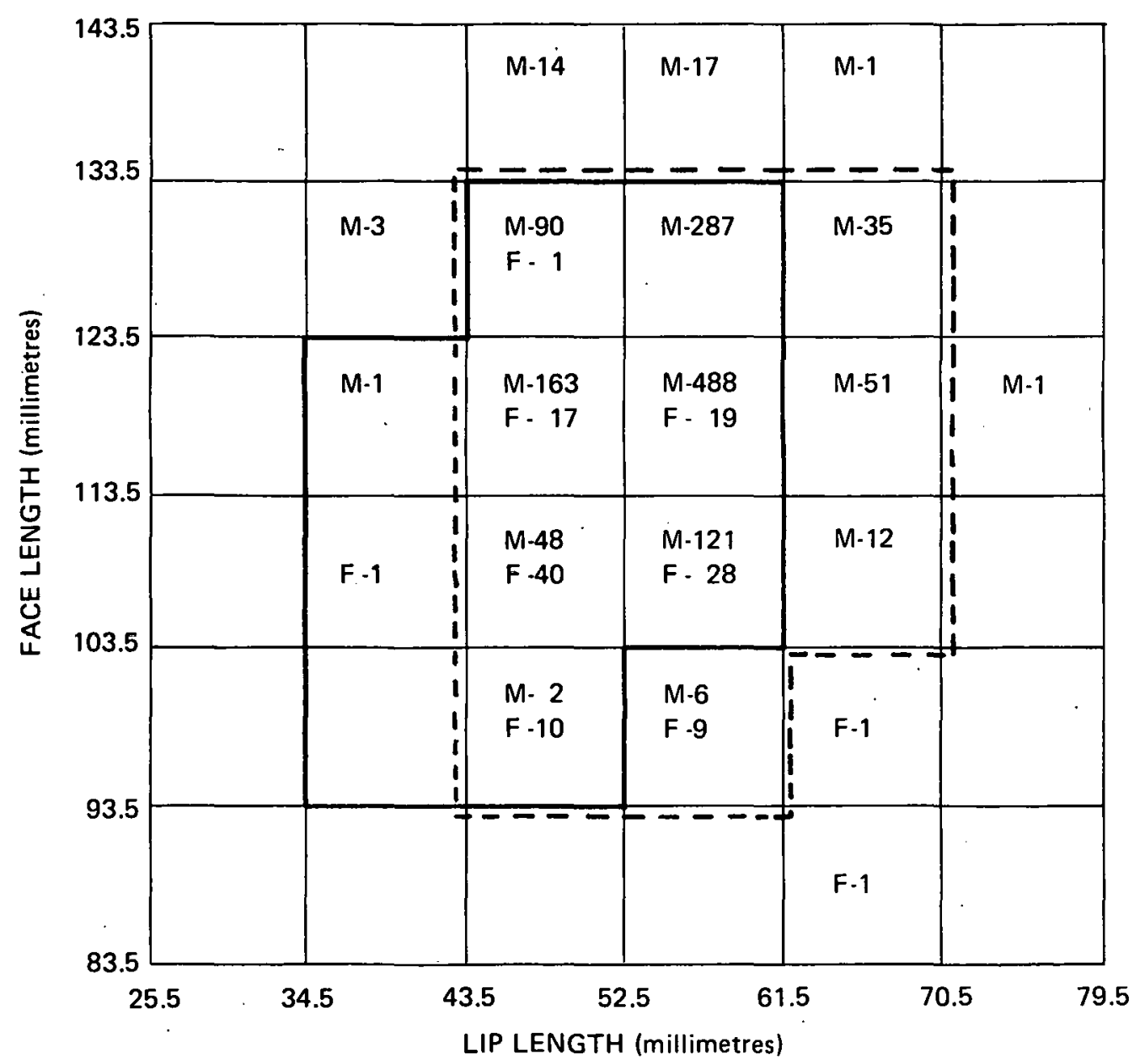


RFP-2358

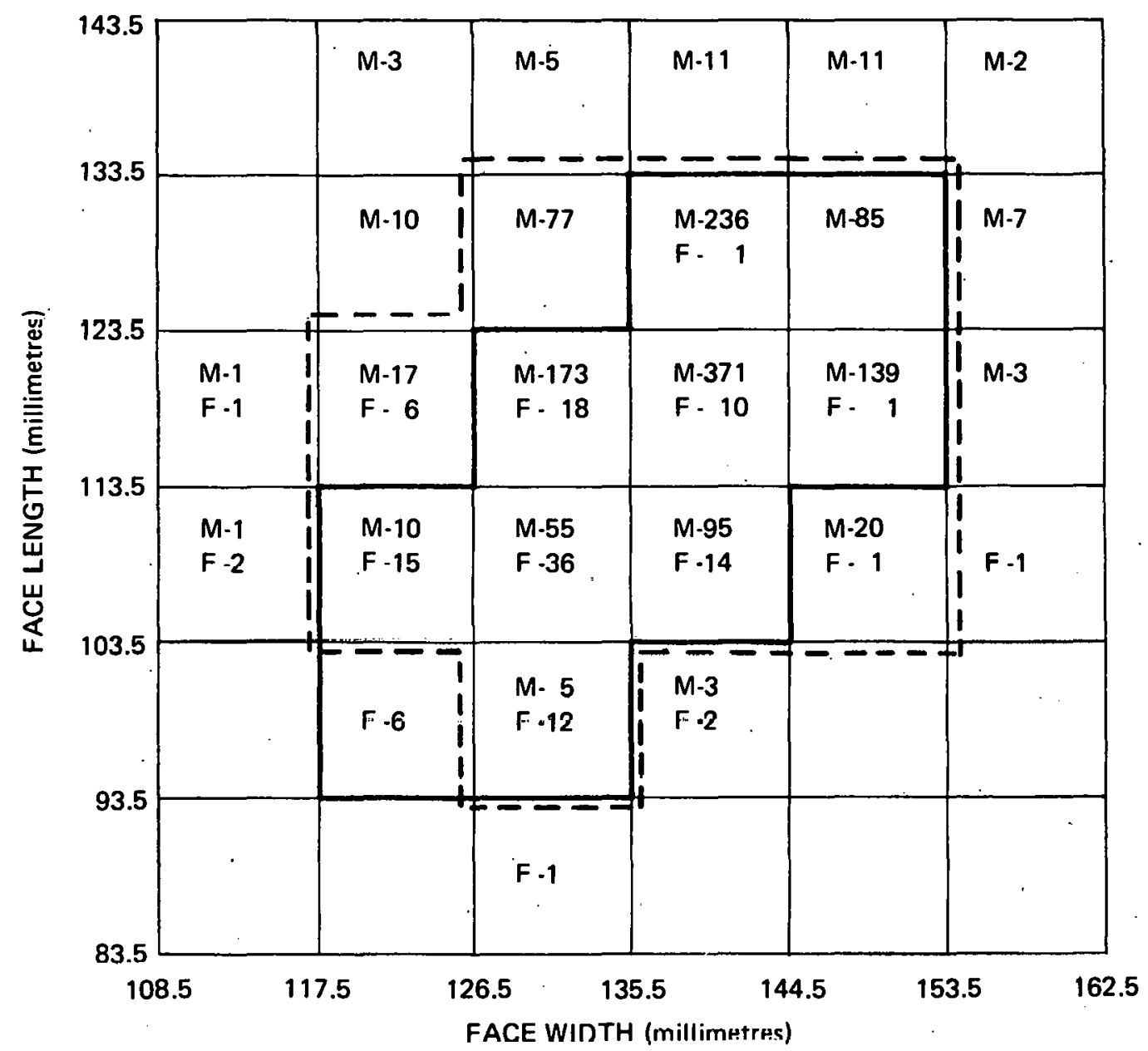

FIGURE 11. Comparative Data for Full Face Masks,

\section{Respirator Man-Tests:}

Disregarding the two employees not tested for a halfmask respirator because of medical limitations, 1,009 employees have been tested. Two employees from that total could not achieve an adequate fit (average leak $>5 \%$, or maximum leak $>10 \%$ ). Using the halfmasks available to Rocky Flats employees, $99.8 \%$ of those tested were able to achieve an adequate fit.

Disregarding the 38 employees not tested for a fullface respirator because of medical limitations or other reasons, 973 employees have been tested. Seven of the 973 employees could not be adequately fitted (average leak $0.5 \%$, or maximum leak $1 \%$ ). Using the full-face respirators available to Rocky Flats employees $99.3 \%$ of those tested were able to achieve an adequate fit.
Assuming these employees are representative of the industrial population, it can be concluded that the test panel, foi bull the half-mask and full-face respirators, is not needed. To reach this conclusion, a qualifying condition must be accepted. The size specifications of the half- and full-face respirators used by Rocky Flats would replace the test panel.

The Respiratory Protection Program in use at Rocky Flats qualifies as one of the best. The program will continue to be upgraded and improved. The health and safety of all employees in government facilities could be significantly upgraded by increasing the quantity and quality of information exchanged between plant groups having similar operations. 